\title{
Landslide occurrence as a response to land use change: a review of evidence from New Zealand
}

\author{
Thomas Glade* \\ Department of Geography, University of Bonn, Meckenheimer Allee 166, 53115 Bonn, Germany
}

Received 19 February 2001; accepted 8 October 2002

\begin{abstract}
Vegetation cover is an important factor influencing the occurrence and movement of rainfalltriggered landslides, and changes to vegetation cover often result in modified landslide behaviour. However, it is difficult to relate the occurrence of landslides directly to variations in land use, especially in some European countries. In contrast, New Zealand provides a good opportunity to investigate geomorphic responses to anthropogenic land cover changes. Before European settlers first arrived in the 1840 s, hilly regions were only marginally influenced by human activity. The Maoris, New Zealand's first settlers, lived largely on coastal plains or near lakes and rivers. They influenced general vegetation cover only through localized burning practices. In contrast, European settlers moved into the back country and converted extensive hill areas from native forest and bush to pasture. This reduced the strength of the regolith and rendered the slopes more susceptible to landslides. Pulses of natural sedimentation in the pre-European period have been related to volcanic activity, climatic variability, including changes in frequency of cyclonic storms and wind erosion and fluvial erosion following forest fires initiated either by volcanic eruptions or lightning strikes. Since European deforestation began, sediment production has largely been determined by landslide events. On unstable slopes, thousands of landslides were triggered by high-magnitude/lowfrequency climatic events during storms with estimated return periods in excess of 50 years. In contrast, low-magnitude/high-frequency rainfall events have caused gully and channel erosion. Examples from different parts of New Zealand indicate changes in sediment-generating processes following land use modifications. After deforestation, landslides have contributed significantly to sediment sequences in depositional basins such as lakes, swamps, estuaries, coastal wetlands and the nearshore and offshore zones of continental platforms.
\end{abstract}

(C) 2002 Elsevier Science B.V. All rights reserved.

Keywords: Landslides; Land use change; Sediment budget; Human activity; Landform response

* Tel.: +49-228-73-9098; fax: +49-228-73-9099.

E-mail address: thomas.glade@uni-bonn.de (T. Glade). 


\section{Introduction}

Land use change has been recognized throughout the world as one of the most important factors influencing the occurrence of rainfall-triggered landslides. Following Cruden and Varnes (1996) and Dikau et al. (1996), the term landslide is used in this review for soil, debris and rock travelling by sliding, flow and complex movement.

Landslide occurrence as a response to land use changes has been studied over various time periods. In the late Holocene, humans converted large areas from native forest and bush into arable land in various areas throughout Europe. Increased activity of geomorphic processes resulted, including aeolian transport and flooding, accelerated sheet and rill erosion, open and tunnel gullying and landsliding. For Europe and other regions, Matthews et al. (1997) reviewed rapid mass movement as a source of palaeoclimatic evidence for the Holocene. Various contributing authors stressed the link between climatic and human impacts on landslide initiation. Examples for the Holocene were given for Germany (Grunert and Hardenbicker, 1997), Scotland (Innes, 1997), Great Britain (Ibsen and Brunsden, 1997) and Italy (Rodolfi, 1997), to name only a few. However, this link is not an ancient phenomenon. Examples from Mt. Ichifusa, Japan (Marutani et al., 2000), Canada (Goff and Hicock, 1995; Goff et al., 1996) and those from New Zealand discussed later in this review demonstrate increased landslide occurrence and effects in downstream sediment sinks with continuing deforestation in recent periods.

When focusing on landslide response to past land use change, a major problem in agricultural areas is the removal of evidence by intense soil cultivation. Consequently, few remnants of older landslides can be recognized (Matthews et al., 1997). Even when they are identified, dating is imprecise, if it is possible at all (Lang et al., 1999), and it is even more difficult to relate landslide occurrence to vegetation changes. Of particular interest is the influence of human activity on vegetation changes. Often, large areas were changed in a short time, thus, influencing strongly the environmental factors, which control landscape stability. Changes should be related to the stratigraphy of colluvial and alluvial sediments, but it is usually impossible to relate these sediments to erosion processes such as sheet and rill erosion, open and tunnel gullying and landslides. Therefore, it is important to investigate in more detail regions such as New Zealand where it seems possible to relate sediment layers to landslide processes.

\section{New Zealand setting}

The vegetation of New Zealand developed during a long period of isolation from any other landmass. Over $85-90 \%$ of the country, the native vegetation developed over thousands of years to a dynamic climax around 3000 BP (McGlone, 1989). There is no simple relationship between vegetation cover and erosion processes. Even under forest regimes, landsliding can be the dominant erosion process (Crozier et al., 1992; Eden and Page, 1998). However, depletion of native vegetation tends to be followed by increased erosion (Trustrum et al., 1990; Page and Trustrum, 1997; Wilmshurst et al., 1999). 
Holocene disturbance of sediments has been related to volcanic activity, climatic variability (Eden and Page, 1998; Page and Trustrum, 2000), wind erosion (Basher and Webb, 1997) and erosion following forest fires initiated by volcanic eruptions (McGlone, 1981; Wilmshurst and McGlone, 1996) or lightning (Burrows, 1996; Wilmshurst et al., 1999). Eden et al. (1994), Trustrum et al. (1999) and Page and Trustrum (2000) have noted pulses of sediment activity that can be related to increased frequency of rainfall and other natural disturbances like fire and volcanic effects.

The environment was relatively undisturbed by human activity until the middle of the 19th century. Before this, the first settlers, Polynesians from the South Pacific Islands, arrived around $1250 \mathrm{AD}$ and became the native inhabitants of New Zealand, the Maoris. Although few in number, they were the first to influence the natural system through slashing and burning the indigenous vegetation over wide areas. About half the forest and scrubland was burned (Poole and Adams, 1994). Although this caused a long-term change of vegetation and irreversible damage (McGlone, 1983; McGlone and Basher, 1995), Maoris were principally active on flat landscapes such as valley floors, plains, coastal regions and forelands (Newnham et al., 1998a). Some sheet erosion, rill erosion and gullying did increase on gentle slopes and degraded the soil, but this occurred only locally, and most slopes remained stable. A Polynesian-induced increase in landslide occurrence is not clearly identifiable from hillslope studies (DeRose et al., 1993), although a $60 \%$ increase in sedimentation rates in one lake basin has been attributed to Polynesian deforestation (Page and Trustrum, 1997). This situation changed suddenly with the arrival of the first European settlers in New Zealand. Within a few years, the Maoris had become a minority (Glade, 1998) and their agricultural practices and influence on the landscape was overshadowed by extensive European forest clearance and conversion to pasture.

Of particular interest for relating landslide occurrence to vegetation change are sedimentary sinks within the landscape such as colluvial bodies, floodplains, lakes and nearshore marine environments. Recent studies of river discharge and suspended sediment load suggest that most of the sediment transported by streams and deposited in these sinks during and following rainstorms has come from landslides and landslidegully complexes in headwater catchments (Hicks et al., 2000). Ultimately, these sediment stores can be used to disentangle the different transport processes. Although nearshore and coastal wetland sinks are also prone to changes from sea-level variations or catastrophic events such as tsunamis, these can be distinguished in the sediment record from human-induced sedimentation (Goff and Chagué-Goff, 1999; Chagué-Goff et al., 2000).

Within a sediment body, deforestation effects can be clearly distinguished from natural impacts by pollen analysis, which shows the introduction of exotic European trees, herbs and pasture by European settlers (Wilmshurst et al., 1997, 1999). This gives a more detailed view of increased erosion resulting from human settlement.

In this review, landslides triggered by rainstorms are distinguished from long-term erosion resulting from other processes in order to filter human activity from natural erosion conditions. The study is based on the hypothesis that deforestation led to increased slope instability. The first large rainstorm following deforestation was able to trigger landslide activity, resulting in higher sedimentation rates. 


\section{Methods}

There have been many case studies relating landslide activity in New Zealand to human interference and the influence of vegetation cover. However, they have been based on a range of different methods, so any conclusions based upon them can only indicate possible linkages between landslide occurrence and land use change. Another problem with using case studies is that different authors have worked on different time scales, in significantly varying environmental settings, using methods specifically designed for their respective aims. Nevertheless, a preliminary review based on analogous interpretations is considered useful in providing perspectives for future investigations.

Information about prehistoric periods is based on pollen analyses of colluvium, floodplain, limnic and coastal deposits (e.g. Newnham et al., 1998b; McGlone and Wilmshurst, 1999; Wilmshurst et al., 1999), ${ }^{14} \mathrm{C}$ dating (e.g. Lowe et al., 1998) and tephrochronology (e.g. Eden and Froggatt, 1996; Lowe et al., 1998; Newnham et al., 1998a).

Historical data were compiled from written documents, drawings and photographs. Sources included archives, newspapers, reports, scientific publications and vertical and oblique aerial photography. The number of historical records increased with population density and with event magnitude (Glade, 1996, 1998). Although this was a general drawback of the inventory, it does not mean that only greater magnitude landslide events are known. Vegetation data since the 19th century were obtained from the New Zealand Statistics yearbooks.

The locations of all study sites are shown in Fig. 1.

\section{Results}

\subsection{Hawke Bay}

Lake Tutira and adjacent Lake Waikapiro (Fig. 2) have acted as sediment sinks since their formation about 6000 years ago (Trustrum and Page, 1992; Page et al., 1994a; Page and Trustrum, 1997; Eden and Page, 1998). Prior to the commencement of European farming activity, finely laminated sediments accumulated in Lake Tutira at rates of 1.5 $2.4 \mathrm{~mm}_{\text {year }}{ }^{-1}$, which increased by about $60 \%$ following Polynesian settlement (Page and Trustrum, 1997). However, based on hillslope studies, DeRose et al. (1993) were unable to find any Polynesian influence, so landslides or other processes such as streambank erosion could have delivered the sediment to the lake.

Since the 1880s, the sedimentation rate in Lake Tutira has increased to approximately $13 \mathrm{~mm}$ year $^{-1}$ (Page and Trustrum, 1997). Historical sources have documented the large

Fig. 1. Location of study sites. Circled numbers refer to locations mentioned in the text: (1) Whangape harbour estuary (Nichol et al., 2000); (2) Repongaere swamp (Wilmshurst et al., 1999); (3) Continental shelf (Wilmshurst et al., 1999); (4) Waipaoa valley floors (Gomez et al., 1998; Marutani et al., 1999; Hicks et al., 2000); (5) Lake Waikaremoana (Newnham et al., 1998b); (6) Lake Tutira (Page et al., 1994a; Trustrum et al., 1999); (7) Wellington harbour (Goff, 1997); (8) Abel Tasman coastal wetlands (Goff and Chagué-Goff, 1999). 


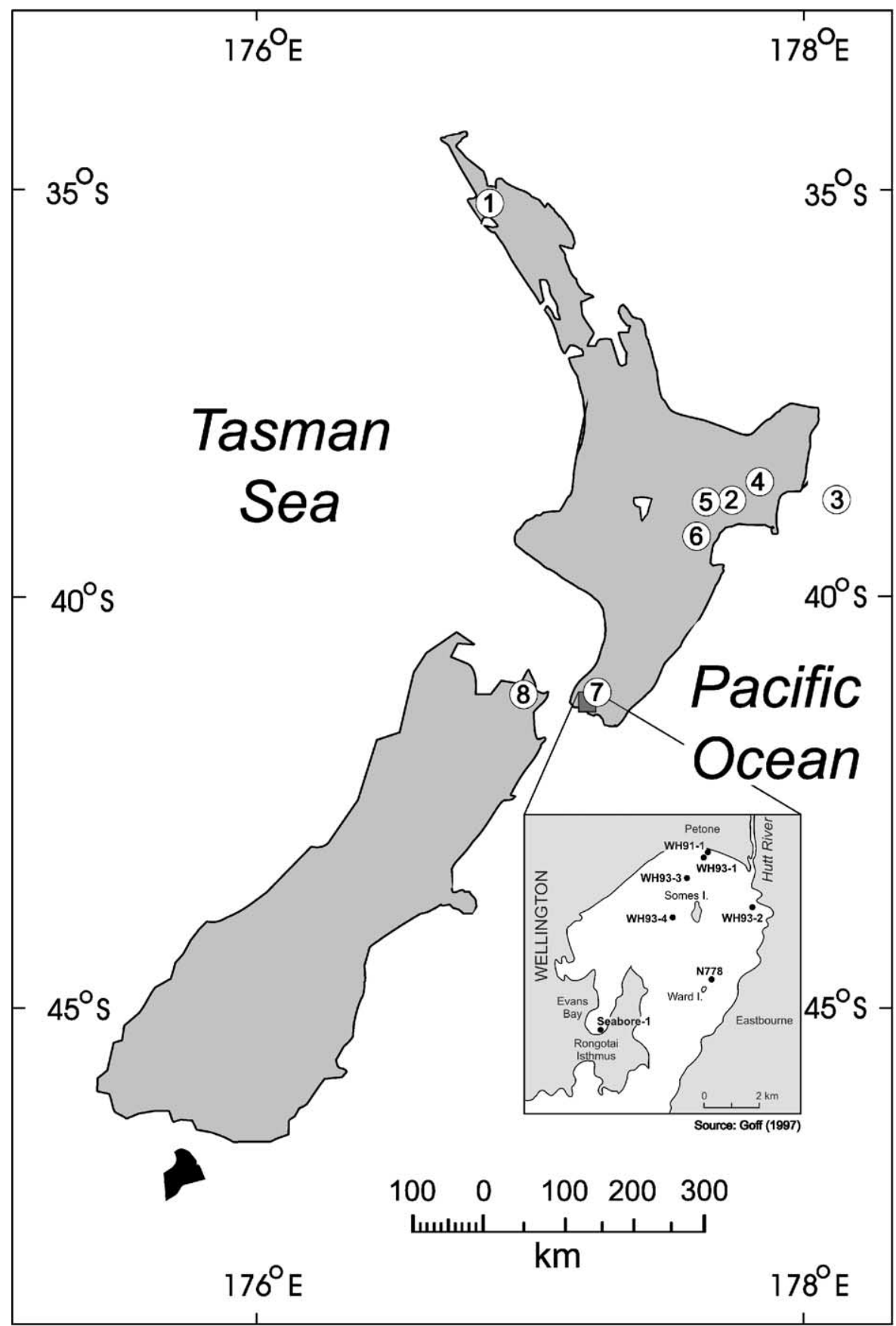




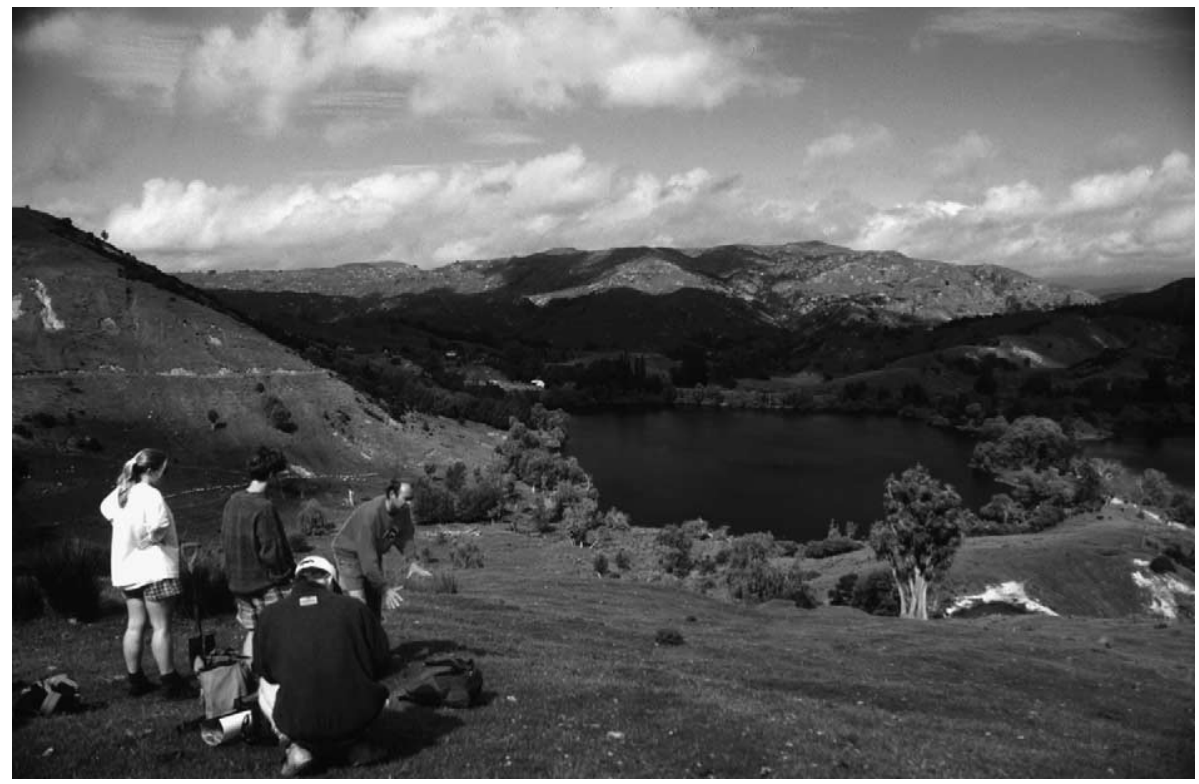

Fig. 2. Freshwater Lake Waikapiro in Hawke Bay, North Island, view towards southwest.

extent of landsliding in this area since the 1880s, particularly in 1938, 1945, 1963, 1965 and 1988. The most active years of landsliding were 1938 and 1988. Page et al. (1994b) were able to correlate sediment thickness with landslide events, and Turner (1997) suggested that low concentrations of magnetic minerals in sediments deposited prior to European settlement indicate that erosion processes in the catchments did not remove strongly minerogenic sediments. Since the arrival of the Europeans, each major rainstorm has produced identifiable pulses of minerogenic sediment, which must be a result of processes mobilizing the regolith. This result strongly suggests increased soil erosion after deforestation. Although sediment pulses triggered by rainstorm events have rapidly infilled the lake basin, no simple relationship between storm magnitude and sediment thickness exists. For example, although rainfall event magnitude was larger in 1988 than in 1938, total sediment delivery was less. This could be explained by:

- The 1938 storm removed much of the sediment that had previously accumulated on the hillside, foot slopes and alluvial plains under native forest and scrub cover (Page et al., 1994b).

- Until 1988, hillside sediments were removed by previous events, thus, sediment sources have been emptied by progressive failures and not enough time had elapsed for soil recovery (Page et al., 1994b; Crozier and Preston, 1999).

Despite this problem, a sediment budget for the Lake Tutira catchment was established for the widespread landslide-triggering rainfall event of March 1988 by Page et al. (1994a). They quantified the amounts of sediment stored on different terrains (e.g. 
hillslopes, floodplains) and compared them to the sediment delivered to the lake. They showed that landslides contributed $89 \%$ to the sediment flux (Table 1); $43 \%$ of the mobilised sediment was stored on foot slopes and valley floors; and 51\% was deposited in the lake.

The transition in landscape sensitivity from stable to potentially unstable conditions following conversion of native forest to farm land by European settlers has been addressed conceptually by Preston (1999) and Preston and Crozier (1999). If the native vegetation cover had still been in place, a similar rainfall event to that of March 1988 would have led to only minor effects on the landscape (Trustrum et al., 1999). Although the effect of climate change cannot be excluded in this region, the changing type or magnitude of geomorphic processes following land use change is apparent, and suggests that land use change is the most important factor leading to increased landslide initiation in this region (Eden and Page, 1998).

\subsection{Wellington}

Wellington Harbour is a natural nearshore sink for sediment inputs from rivers draining a basin area of approximately $85 \mathrm{~km}^{2}$. The Harbour has a mean depth of $14 \mathrm{~m}$ with the Hutt River flowing into the northern end. Disturbance of sediment by ocean currents is minor because the Harbour has just one outlet to the south. Flows follow a clockwise path in the Harbour during flood tides and anticlockwise at ebb, but the effects on sediment dispersal are unknown. Goff (1997) used seven sediment cores to establish a Holocene sedimentation chronology, which shows the impact of colonisation since 1855 (Table 2). Rapid large-scale deforestation began with the arrival of the first European settlers in 1840 (Dunbar et al., 1997). In subsequent rainstorm events, the exposed soil cover was highly susceptible to erosion, resulting in an increase in sediment accumulation rates. Although sedimentation rates can be influenced by earthquakes and related uplift and the Holocene marine transgression, as well as by anthropogenic influences, Goff (1997) concluded that high-magnitude earthquake events only affect the harbour sediments near the area of uplift, and that anthropogenic influences have a far more significant effect on sediment accumulations. These conclusions are supported by increases in trace metal contents in the

Table 1

Sediment budget of an erosion-inducing rainstorm (Cyclone Bola, 8-11 March, 1988) in Lake Tutira catchment, Hawke Bay

\begin{tabular}{lllll}
\hline Budget component & Location & Process & Sediment flux (\%) & Total (\%) \\
\hline Input & Hillslopes & Landslide & 89 \\
& & Sheet erosion & 7 & \\
& & Tunnel gully & 2 & 100 \\
Valley floors & Channel & 2 & \\
Storage & Hillslopes & Deposition & 21 & 22 \\
& Valley floors & Deposition & 51 & 100 \\
\hline
\end{tabular}

From Page et al. (1994a,b). 
Table 2

Estimated sedimentation rates $\left(\mathrm{mm}_{\mathrm{year}}{ }^{-1}\right)$ of specific periods for various cores in Wellington Harbour

\begin{tabular}{llllllll}
\hline Period & WH92-1 & WH93-1 & WH93-2 & WH93-3 & WH93-4 & SB-1 & N778 \\
\hline $\begin{array}{l}\text { Surface } \\
\text { To } 1963 / 1964^{\mathrm{a}}\end{array}$ & $23.5-26.5$ & $60.0-61.0$ & 150 & 160 & 60 & 205 & $11.0-12.5$ \\
To $1952 / 1953^{\mathrm{a}}$ & & & & & & & \\
To $1910^{\mathrm{b}}$ & & 95 & 40 & & 28 & \\
To $1890^{\mathrm{c}}$ & & $17.0-20.5$ & & 75 & 55 & 550 \\
To $1855^{\mathrm{d}}$ & 370 & 285 & $0.11-0.52$ & $0.7-1.25$ & 4 & $2.1-6.5$ \\
Pre-1855 & $0.5-0.7$ & $0.5-0.7$ & & & & \\
\hline
\end{tabular}

Data summarized from Goff (1997).

a ${ }^{137} \mathrm{Cs}$.

b Pollutants.

c Pinus.

${ }^{\mathrm{d}}$ Earthquake.

${ }^{14} \mathrm{C}$.

harbour sediments, which provide an accurate historical baseline to determine minimum sedimentation rates since the 1920s (Dickinson et al., 1996; Pilotto et al., 1998).

A sediment budget differentiating sediment sources and sinks and associated processes, similar to that for Lake Tutira, has yet to be developed for the Wellington region. However, a study of geomorphic and hydrological effects of a rainstorm event in December 1976 documented that 78 landslides with a total volume of $33,500 \mathrm{~m}^{3}$ contributed significantly to the sediment loads of rivers (McConchie, 1977, 1980). This storm produced 250-300 $\mathrm{mm}$ rainfall in $12 \mathrm{~h}$ and had a return period in excess of 100 years (Tomlinson, 1977). McConchie (1980) stated that, 'Seventy of the landslides provided debris directly to the drainage system producing a highly loaded torrent which caused severe flooding downstream'. Thus, landslides contributed significantly to river sediment load and were dominantly responsible for sediment accumulation in Wellington Harbour. This conclusion is supported by other landslide studies in the Wellington region, which have indicated a relationship between land cover and landslide occurrence (e.g. Eyles et al., 1974a,b; Crozier et al., 1978; Kingsbury, 1994).

\subsection{Further indicators}

In addition to the local studies of Lake Tutira in Hawke Bay and Wellington Harbour, there are further indications from environments throughout New Zealand that land use change was accompanied by an increase in landslide occurrence, which contributed significantly to sediment deposition. Data are summarized by sink types.

\subsubsection{Estuary}

Whangape Harbour is on the western coast of Northland, North Island (Location 1 in Fig. 1). The coastal landscape here was heavily influenced by Polynesian settlers (Nichol et al., 2000). Europeans continued forest burning and introduced logging and grazing. Processes such as river bank collapse, gully erosion and landslides resulting from deforestation have contributed to sedimentation in the estuary, leading to an expansion 
of mangrove forests and deterioration in the quality and quantity of sea food stocks. Nichol et al. (2000) stated: 'The hillslopes of Whangape Harbour catchment are scarred by the effects of rill scour, gully erosion and mass movements, covering an area of approximately $80 \mathrm{~km}^{2}$, In an event in 1999, numerous landslips and boulder debris flows extended onto mangroves in the harbour. Although Nichol et al. (2000) did not quantify the contribution of individual erosional processes to sediment deposition, landslides were of major importance.

Sedimentation rates of $0.1-0.5 \mathrm{~mm}$ year $^{-1}$ in forested landscapes of Polynesian times increased to 1.7-4.6 $\mathrm{mm}_{\text {year }}{ }^{-1}$ following deforestation in the European period (Nichol et al., 2000). Because of recent disturbance and drainage, most pollen profiles in Northland unfortunately do not record approximately the last 1500 years of history (Newnham, 1999) and, thus, do not detail geomorphic response to European disturbance to native forest cover. However, human impact is visible in increased sedimentation and as shown by changes in magnetic susceptibility of the sediment, can be attributed particularly to landslide processes (Nichol et al., 2000).

\subsubsection{Swamps}

In Repongaere Swamp, located in northern Hawke Bay, North Island (Location 2 in Fig. 1), the vegetation was disturbed by volcanism (e.g. the post-Taupo forest disturbance) and lightning strike fires (e.g. Wilmshurst et al., 1999). Although an increased storminess is indicated ca. 2090-1855 years BP by sediment analysis (Wilmshurst et al., 1999), an increase of sediment input can be attributed to Polynesian deforestation AD 1350 (Lowe et al., 1998). However, the highest sedimentation rates followed European pastoralism (Wilmshurst et al., 1999). Although it is not quantified, fluvial sheet wash and in particular landslides may have strongly influenced sediment delivered to Repongaere Swamp. This hypothesis is strengthened by observations on late Holocene lake sediments in the same region by Eden and Page (1998). They concluded that storm sediment pulses identified in lake sediment cores are mainly derived from landslides.

\subsubsection{Continental shelf}

East of Poverty Bay, northeastern North Island (Location 3 in Fig. 1), a marine core from the continental shelf showed from sediment and pollen analysis that sedimentation rates increased by an order of magnitude after European conversion of native scrub and forest to pasture (Wilmshurst et al., 1999). Although the core location was susceptible to sediment disturbance, increased sedimentation after deforestation of the eastern Hawke Bay Region, Gisborne and East Cape was confirmed in the core. Foster and Carter (1997) concluded that the Holocene sedimentation rate on the continental shelf was nearly five times less than the rate since European deforestation.

Detailed studies in the Waipaoa catchment, the largest tributary to Poverty Bay and New Zealand's fourth largest river in terms of sediment supply, indicate that gully-mass movement complexes have been a major contributor to sediment delivery (Marutani et al., 1999; Reid and Page, 2003) (Fig. 3). During intense rainstorms such as Cyclone Bola in 1988, sediments generated by landslides may contribute about half of the total suspended sediment load, as Page et al. (1999) and Trustrum et al. (1999) have shown for of the Kanakanaia River, a major tributary to the Waipaoa River. The large gully-mass move- 


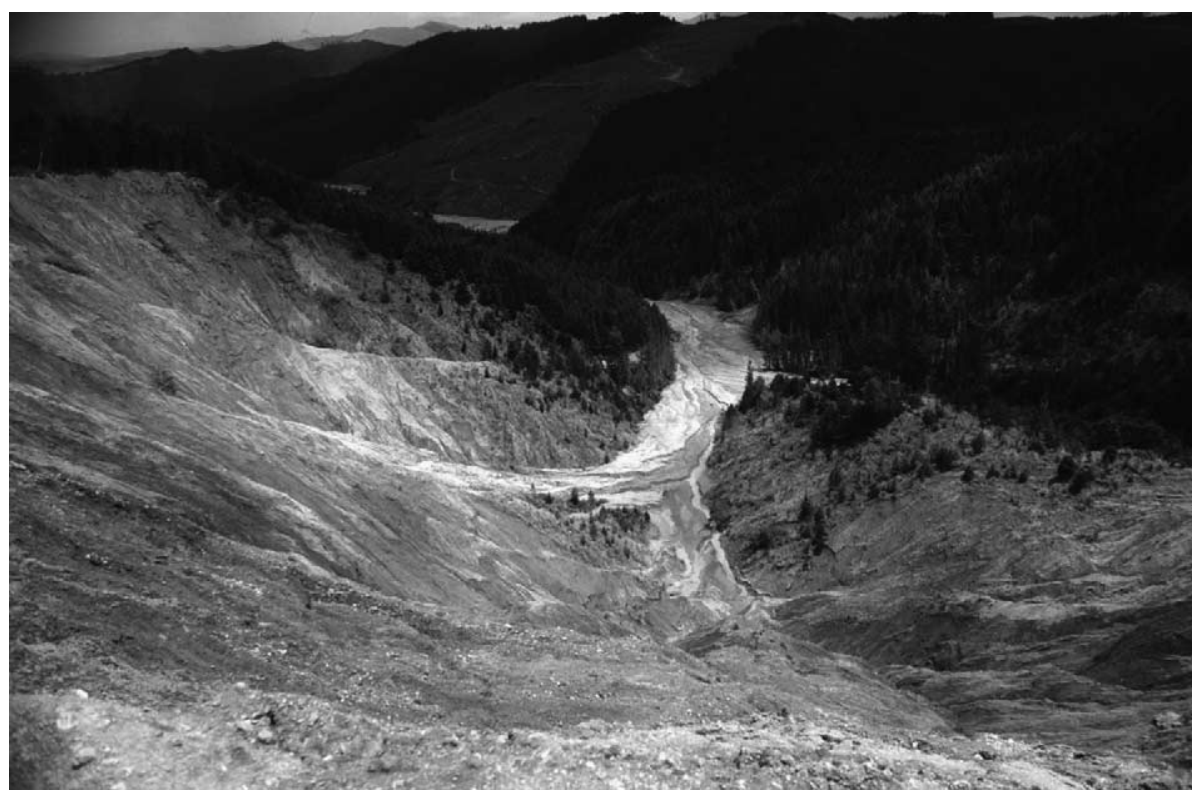

Fig. 3. Tarndale gully complex with aggregated river bed in the Waipaoa catchment, Gisborne, North Island.

ment complexes in this catchment are different from the landslides of other regions, where the dominant landslide types are shallow translational earth and debris slides and flows.

\subsubsection{Valley floors}

Sediment sources, pathways and sinks have been extensively investigated in the Waipaoa catchment (Location 4 in Fig. 1, Fig. 4). Gomez et al. (1998) and Marutani et al. (1999) measured river discharge and sediment concentrations, and surveyed crosssections to determine changes of sediment storage for the Matakonekone and Oil Springs streams. In these catchments, heavy storms instantaneously aggrade river terraces, but the stored sediments are then gradually excavated by fluvial transport.

DeRose et al. (1998) and Reid and Page (2003) noted that for the period of investigation, large amounts of fine sediments are delivered to stream channels by gullies and shallow landslides. However, they recognized the importance of frequency and magnitude of triggering rainstorm events with respect to the geomorphic processes that generate sediment. Small frequent rainstorms activate gully erosion, but high-magnitude, infrequent rainstorms trigger shallow landslides in particular (Page et al., 1999; Trustrum et al., 1999). Besides the immediate input, the landslide scars and tails generate sediment for a 1-2-year period following heavy storms. Thereafter, both scars and tails are stabilized and revegetated (Hicks et al., 2000). In contrast, during high-magnitude rainstorms in subcatchments other than Matakonekone and Oil Springs valleys, existing gullies are enlarged and additional landslides generate further sediment, thus, increasing sediment availability. Hicks et al. (2000) measured enhanced suspended sediment load from these subcatchments for a period of approximately 3 years after such storms. Thus, 


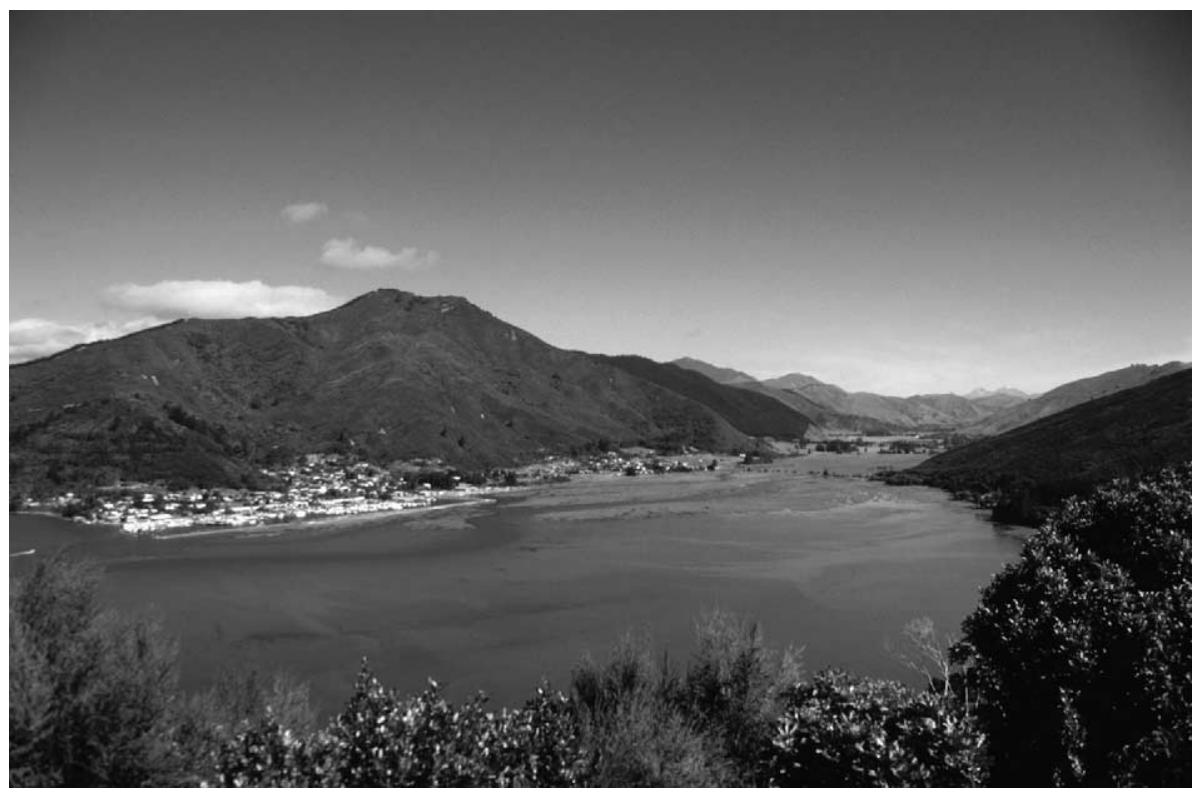

Fig. 4. Coastal wetland in the Marlborough Sounds, Northwest South Island.

heavy rainstorms in all the subcatchments have a longer term geomorphic impact than that during the event itself, and sediment generated by landslides during a single storm remains available for continuing erosion in high-frequency, low-magnitude events. This material contributes significantly to suspended sediment loads following large events.

Sediment from landslides contributes on average $10-19 \%$ of the suspended sediment loads of the Waipaoa River at Kanakanaia. However, this proportion can increase to 50\% during large magnitude rainstorms (Reid and Page, 2003). Therefore, in the Waipaoa catchment, landslides and gully erosion provide most of the suspended sediment, which may be restored on alluvial plains (Marutani et al., 1999).

In addition to the long-term effect of secondary storage, DeRose et al. (1998, p. 1053) conclude that '... the amount of sediment contributed to the river system from extensive mass movements (e.g. earthflows and slumps) and from surface erosion processes in other parts of the catchment, though unquantified, is thought to be considerable'. In summary, Waipaoa studies show that both gully and landslide erosion have accelerated after human deforestation of catchments. However, the contribution of each erosion process to sediment mobilisation and deposition could have changed over time.

\subsubsection{Lake sedimentation}

From sediment cores derived from Lake Waikaremoana (Location 5 in Fig. 1), located in northern Hawke Bay, North Island, Newnham et al. (1998b) delineated a 1850-year tephropalynological record indicating that anthropogenic forest clearance occurred 375 ${ }^{14} \mathrm{C}$ years BP (ca. AD 1523-1631). This date is later than Polynesian inputs elsewhere, but the region is remote, and has never been extensively cleared in historic time, so the 
clearance was probably localized. Newnham et al. (1998b) suggested that around $1150{ }^{14} \mathrm{C}$ years BP (ca. AD 1025-977), there was a short-lived change in sediment supply, from shoreline erosion to stream input. They suggested that storms, snowfall damage, landslides and even recent tephra fall have also been responsible for short-term episodic interruption of the forest cover throughout the history of the lake. Although the effect of landslides was not quantified, they suggested that landslides were an important sediment-delivering process.

\subsubsection{Coastal wetlands}

Goff and Chagué-Goff (1999) took three cores from adjacent coastal wetlands in Abel Tasman National Park (Location 6 in Fig. 1; a similar environment is shown in Fig. 4). They determined pre-European sedimentation rates of $0.5-1.7 \mathrm{~mm}_{\text {year }}{ }^{-1}$ and postEuropean rates of 1.6-2.7 mm year ${ }^{-1}$, rising to $2.3-3.3 \mathrm{~mm}_{\text {year }}{ }^{-1}$ in the last 30 years. They did not investigate the origin of the sediment nor did they assess a sediment budget. However, assuming a similar catchment response to removal of an originally dense native forest (O'Loughlin, 1974; Montgomery et al., 2000), it is suggested that landslides contributed significantly to these increased sedimentation rates. This interpretation is supported by Goff (personal communication, 2001).

\section{Discussion and conclusions}

All studies discussed in this review demonstrate increased sedimentation after the arrival of European settlers and farmers in New Zealand. However, climate variability can also influence sedimentation rates. As Eden and Page (1998) pointed out, some Holocene erosion periods for the Lake Tutira region (Page and Trustrum, 1997) are not represented in the nationwide sequence of distinct and synchronous periods of increased sedimentation recognized by Grant $(1985,1989,1994)$ and McFadgen (1985, 1989, 1994). Eden and Page (1998) argue that this is because the fine resolution of the local Lake Tutira chronology shows shorter erosion periods over the last approximately 2250 years than the more coarsely resolved chronologies based on geographically widespread data extending back to the Taupo Tephra (1718 cal. years BP). Nevertheless, all chronologies attribute increased erosion in headwaters to climatic episodes such as increased frequency of tropical and extratropical cyclonic storms. Under native forest, bracken, fern and scrub, landslides were not so common because of protection by the dense native vegetation cover. This is supported by the early investigations of O'Loughlin (1984), which demonstrated enhanced slope stability through the mechanical reinforcement provided by tree root systems. Similar findings were documented by Phillips and Watson (1994), and are supported by observations of different landslide density in areas of different vegetation cover areas following two distinct rainstorm events (Phillips et al., 1990).

Polynesian and Maori culture changed the vegetation, but only near coasts, rivers and inland lakes and swamps. Although Page and Trustrum (1997) demonstrated the influence of Maori activity on hillslope stability, these effects were limited to areas surrounding their settlements. Maori activity did not significantly affect general slope stability. With the 
arrival of European settlers and farmers about 1850, not only the flat plains but also the steep slopes were cleared of native forest for farming purposes. In 1991, only $6.2 \mathrm{M}$ ha of forest (including exotic and plantation forests) remained (Poole and Adams, 1994) from the 16.2 $\mathrm{M}$ ha of native forest cover of the pre-European period (Newsome, 1987). The environmental change brought about by this deforestation is recognizable in increased sedimentation rates in swamp, lake, coastal and marine environments (Table 3). To compare the different environments, the change from the pre-European to the European period is expressed by the factor of increase, defined as the ratio between post-European and pre-European sedimentation rates. Although the factor ranges between 1.6 and 18.2, it demonstrates an increased sediment accumulation through deforestation for all sinks and environments.

Sediment pulses during historic and Holocene times suggest that sediment generation in New Zealand is particularly related to landslide erosion (e.g. Page et al., 1994a; Eden and Page, 1998). Landslides contribute significantly to sediment accretion rates on lake beds (e.g. Page et al., 1994b) and in fluvial environments (Marutani et al., 1999). However, most recent studies suggest the need to differentiate between low-magnitude/highfrequency and high-magnitude/low-frequency events. In the Waipaoa catchment, for example, high-magnitude/low-frequency events seem to be less important for total sediment yield than the cumulative influence of low-magnitude/high-frequency events. Although landslides contribute to the high-magnitude events, lower magnitude storms generate more sediment through erosional processes such as gully and stream bank erosion (Page et al., 1999; Trustrum et al., 1999; Reid and Page, 2003).

Contemporary landscapes reflect, to differing degrees, the impacts of prior erosional processes. Landsliding was probably not the dominant initial erosional process in the Waiapaoa catchment. However, over time, the contribution of each erosional process changed. For example, large slow-moving mudslides and earthflows are known to have occurred in the past, with histories of movement and accumulation that probably span

Table 3

Evidence of increased sediment accretion rates following human settlement

\begin{tabular}{lllr}
\hline & $\begin{array}{l}\text { European } \\
\text { (pasture) rate } \\
(\text { mm year }\end{array}$ & $\begin{array}{l}\text { Polynesian } \\
\text { (scrub-fern) or } \\
\text { pre-Polynesian (forest) } \\
\text { rate (mm year }{ }^{-1} \text { ) }\end{array}$ & $\begin{array}{r}\text { Factor of } \\
\text { increase }\end{array}$ \\
\hline Whangape Harbour (estuary) $^{\mathrm{a}}$ & $1.7-4.6$ & $0.1-0.5$ & $9.2-17$ \\
Repongaere (swamp) $^{\mathrm{b}}$ & 3.6 & 0.3 & 12 \\
Poverty Bay (continental shelf) $^{\mathrm{b}}$ & 3.7 & 0.3 & 12.3 \\
Lake Tutira (freshwater lake) $^{\mathrm{c}}$ & 14.0 & 2.1 & 6.7 \\
Wellington Harbour (near coast) $^{\mathrm{d}}$ & 38.2 & 2.1 & 18.2 \\
Abel Tasman (coastal wetland) $^{\mathrm{e}}$ & $1.6-2.7$ & $0.5-1.7$ & $1.6-3.2$ \\
\hline
\end{tabular}

Factor of increase $=$ post-European sedimentation rate/pre-European sedimentation rate.

${ }^{\mathrm{a}}$ Nichol et al. (2000).

${ }^{\mathrm{b}}$ Wilmshurst et al. (1999).

${ }^{c}$ Page et al. (1994a,b); Trustrum and Page (1992).

d Goff (1997).

${ }^{\text {e }}$ Chagué-Goff et al. (2000). 
thousands of years. On the other hand, initially small landslides evolved into large gully complexes, which now dominate the sediment supply to the rivers. Sediment exhaustion is an additional key control on landslide activity.

The temporal and spatial response of erosional processes, particularly landsliding, to climatic impacts may vary greatly within and especially between catchments. With each triggering rainfall, landslide locations change within a given catchment. Also landslide responses to the same rainfall event vary significantly in different catchments. As the Lake Tutira catchment shows, smaller frequent rainstorms result in a greater volume of deposits than the few large magnitude events (e.g. Page et al., 1994b). Depositional response may be buffered by:

1. temporary storage on foot slopes or alluvial plains;

2. timing of processes (e.g. landslides following peak discharges may be followed by processes with lower transport capacities, which slowly remove the landslide material);

3. the general temporal and spatial variability of triggering storms and of the distribution of erosional processes; and

4. variation of land use and vegetation type.

Given the greater sensitivity of landscapes to disturbance following vegetation clearance, tropical cyclones of a relatively small magnitude probably affect larger areas than before land use change.

From the case studies reviewed here, the response to forest clearance seems to have been manifested primarily through increased rates of landslide activity, which have contributed to sediment accumulations downstream (e.g. Page et al., 1994a; Hicks et al., 2000). Although there is some temptation to accept this hypothesis, further investigations are necessary to confirm it. The case studies that have demonstrated the influence of landslides on depositional regimes following deforestation in the Hawke Bay and East Cape region need to be supported by parallel studies in other depositional environments such as coastal and inland swamps, estuaries, nearshore and offshore areas. Further studies might include:

1. detailed analysis of aerial photo sequences to detect land use changes and erosion response with particular focus on landslide occurrences;

2. coring colluvial foot slopes and alluvial plains in order to determine storage capacity and transport rates between slopes and sinks;

3. assessments of sediment budgets following both low-magnitude/high-frequency and high-magnitude/low-frequency landslide-triggering rainstorm events (Trustrum et al., 1999), and extrapolation of these local results to longer time periods ( $>50$ years);

4. linkage of sediment sources, pathways and sinks to determine the most important factors for sediment generation and distribution throughout a catchment (Trustrum et al., 1999) and between catchments of various sizes (Wilmshurst, 1997);

5. temporal analysis of how erosion processes evolve in response to land use change; and

6. determination of the current sensitivity of various landscapes to landsliding (Thomas, 2001), particularly with respect to the relationship between single landslide events and specific event sequences (Brunsden, 2001). 


\section{Acknowledgements}

I thank Noel Trustrum and James Goff for fruitful discussions during the course of data collection. Mike Crozier contributed through his continuous support. Nick Preston is thanked for numerous comments on an early copy of this manuscript. Noel Trustrum, Russell Blong and an anonymous referee helped to improve the manuscript significantly. Gary Brierley and John Catt provided helpful editorial comments.

\section{References}

Basher, L.R., Webb, T.H., 1997. Wind erosion rates on terraces in the Mackenzie Basin. Journal of the Royal Society of New Zealand 27, 499-512.

Brunsden, D., 2001. A critical assessment of the sensitivity concept in geomorphology. Catena 42, 99-123.

Burrows, C.J., 1996. Radiocarbon dates for Holocene fires and associated events, Canterbury, New Zealand. New Zealand Journal of Botany 34, 111-121.

Chagué-Goff, C., Nichol, S.L., Jenkinson, A.V., Heijnis, H., 2000. Signatures of natural catastrophic events and anthropogenic impact in an estuarine environment, New Zealand. Marine Geology 167, 285-301.

Crozier, M.J., Preston, N.J., 1999. Modelling changes in terrain resistance as a component of landform evolution in unstable hill country. In: Hergarten, S., Neugebauer, H.J. (Eds.), Process Modelling and Landform Evolution. Lecture Notes in Earth Sciences. Springer, Heidelberg, pp. 267-284.

Crozier, M.J., Eyles, R.J., Wheeler, R.H., 1978. Landslips in Wellington City. New Zealand Geographer 34, $58-74$.

Crozier, M.J., Gage, M., Pettinga, J.R., Selby, M.J., Wasson, R.J., 1992. The stability of hillslopes. In: Soons, J.M., Selby, M.J. (Eds.), Landforms of New Zealand. Longman Paul, Auckland, pp. 63-90.

Cruden, D.M., Varnes, D.J., 1996. Landslide types and processes. In: Turner, A.K., Schuster, R.L. (Eds.), Landslides: Investigation and Mitigation. Special Report. National Academy Press, Washington, DC, pp. 36-75.

DeRose, R.C., Trustrum, N.A., Blaschke, P.M., 1993. Post-deforestation soil loss from steepland hillslopes in Taranaki, New Zealand. Earth Surface Processes and Landforms 18, 131-144.

DeRose, R.C., Gomez, B., Marden, M.J., Trustrum, N.A., 1998. Gully erosion in Mangatu Forest, New Zealand, estimated from digital elevation models. Earth Surface Processes and Landforms 23, 1045-1053.

Dickinson, W.W., Dunbar, G.B., McLeod, H., 1996. Heavy metal history from cores in Wellington Harbour, New Zealand. Environmental Geology 27, 59-69.

Dikau, R., Brunsden, D., Schrott, L., Ibsen, M. (Eds.), 1996. Landslide Recognition. Identification, Movement and Causes. Wiley, Chichester, $251 \mathrm{pp}$.

Dunbar, G.B., McLea, B., Goff, J.R., 1997. Holocene pollen stratigraphy and sedimentation, Wellington Harbour, New Zealand. New Zealand Journal of Geology and Geophysics 40, 325-333.

Eden, D.N., Froggatt, P.C., 1996. A 6500-year-old history of tephra deposition recorded in the sediments of Lake Tutira, eastern North Island, New Zealand. Quaternary International 34-36, 55-64.

Eden, D.N., Page, M.J., 1998. Palaeoclimatic implications of a storm erosion record from late Holocene lake sediments, North Islands, New Zealand. Palaeogeography, Palaeoclimatology, Palaeoecology 139, 37-58.

Eden, D.N., Froggatt, P.C., Trustrum, N.A., Page, M.J., 1994. A multiple-source Holocene tephra sequence from Lake Tutira, Hawke's Bay, New Zealand. New Zealand Journal of Geology and Geophysics 36, $233-242$.

Eyles, R.J., Crozier, M.J., Wheeler, R.H., 1974a. Landslides in Wellington City. Soil and Water 11, 17-20.

Eyles, R.J., Crozier, M.J., Wheeler, R.H., 1974b. Landslips in Wellington City. New Zealand Geographer 34, $58-74$.

Foster, G., Carter, L., 1997. Mud sedimentation on the continental shelf at an accretionary margin-Poverty Bay, New Zealand. New Zealand Journal of Geology and Geophysics 40, 157-173.

Glade, T., 1996. The temporal and spatial occurrence of landslide-triggering rainstorms in New Zealand. In: Mäusbacher, R., Schulte, A. (Eds.), Beiträge zur Physiogeographie-Festschrift für Dietrich BarschHeidel- 
berger Geographische Arbeiten. Selbstverlag des Geographischen Instituts der Universität Heidelberg, Heidelberg, pp. 237-250.

Glade, T., 1998. Establishing the frequency and magnitude of landslide-triggering rainstorm events in New Zealand. Environmental Geology 35, 160-174.

Goff, J.R., 1997. A chronology of natural and anthropogenic influences on coastal sedimentation, New Zealand. Marine Geology 138, 105-117.

Goff, J.R., Chagué-Goff, C., 1999. A late Holocene record of environmental changes from coastal wetlands: Abel Tasman National Park, New Zealand. Quaternary International 56, 39-51.

Goff, J.R., Hicock, S.R., 1995. Origin of downstream variation in clast size in a small mountain catchment, British Columbia. Geographical Review of Japan. Series B 2, 213-221.

Goff, J.R., Hicock, S.R., Hamilton, T.D., 1996. Recent Holocene changes in sedimentation in a landslidedammed lake in the Cascade Mountains, Southwestern British Columbia. Holocene 6, 75-81.

Gomez, B., Eden, D.N., Peacock, D.H., Pinkney, E.J., 1998. Floodplain construction by recent, rapid vertical accretion: Waipaoa River, New Zealand. Earth Surface Processes and Landforms 32, 405-413.

Grant, P.J., 1985. Major periods of erosion and alluvial sedimentation in New Zealand during the late Holocene. Journal of the Royal Society of New Zealand 15, 67-121.

Grant, P.J., 1989. Effects on New Zealand vegetation of Late Holocene erosion and alluvial sedimentation. New Zealand Journal of Ecology 12, 131-144.

Grant, P.J., 1994. Late Holocene histories of climate, geomorphology and vegetation, and their effects on the first New Zealanders. In: Sutton, D.G. (Ed.), The Origins of the First New Zealanders. Auckland Univ. Press, Auckland, pp. 164-194.

Grunert, J., Hardenbicker, U., 1997. The frequency of landsliding in the north Rhine area and possible climatic implications. In: Matthews, J.A., Brunsden, D., Frenzel, B., Gläser, B., Weiß, M.M. (Eds.), Rapid Mass Movement as a Source of Climatic Evidence for the Holocene. Palaeoclimate Research. Gustav Fischer Verlag, Stuttgart, pp. 159-170.

Hicks, D.M., Gomez, B., Trustrum, N.A., 2000. Erosion thresholds and suspended sediment yields, Waipaoa River Basin, New Zealand. Water Resources Research 36, 1129-1142.

Ibsen, M.-L., Brunsden, D., 1997. Mass movement and climatic variation on the south coast of Great Britain. In: Matthews, J.A., Brunsden, D., Frenzel, B., Gläser, B., Weiß, M.M. (Eds.), Rapid Mass Movement as a Source of Climatic Evidence for the Holocene. Palaeoclimate Research. Gustav Fischer Verlag, Stuttgart, pp. 171-182.

Innes, J.L., 1997. Historical debris-flow activity and climate in Scotland. In: Matthews, J.A., Brunsden, D., Frenzel, B., Gläser, B., Weiß, M.M. (Eds.), Rapid Mass Movement as a Source of Climatic Evidence for the Holocene. Palaeoclimate Research. Gustav Fischer Verlag, Stuttgart, pp. 233-240.

Kingsbury, P.A., 1994. Preliminary assessment of the Johnson Hill landslide, Palliser Bay. Contract report 94.205. Wellington Regional Council, Wellington.

Lang, A., Moya, J., Corominas, J., Schrott, L., Dikau, R., 1999. Classic and new dating methods for assessing the temporal occurrence of mass movements. Geomorphology 30,33-52.

Lowe, D.J., McFadgen, B.G., Higham, T.F.G., Hogg, A.G., Froggatt, P.C., Nairn, I.A., 1998. Radiocarbon age of the Kaharoa Tephra, a key marker for late Holocene stratigraphy and archaeology in New Zealand. Holocene $8,487-495$.

Marutani, T., Kasai, M., Reid, L.M., Trustrum, N.A., 1999. Influence of storm-related sediment storage on the sediment delivery from tributary catchments in the upper Waipaoa River, New Zealand. Earth Surface Processes and Landforms 24, 881-896.

Marutani, T., Kasai, M., Ebisu, N., Trustrum, N.A., 2000. Sediment Generation from Numerous Shallow Landslides Related with Clear Cutting at Granite Mountain, Mt. Ichifusa, Japan. Internationales Symposion INTERPRAEVENT 2000. Österreich, Villach, pp. 271-279.

Matthews, J.A., Brunsden, D., Frenzel, B., Gläser, B., Weiß, M.M. (Eds.), 1997. Rapid Mass Movement as a Source of Climatic Evidence for the Holocene. Paläoklimaforschung Paleoclimate Research, vol. 19. Gustav Fischer Verlag, Stuttgart, 444 pp.

McConchie, J.A., 1977. The geomorphological and hydrological response to the 20 December 1976 storm, Stokes Valley. Unpublished BSc (Hons) thesis, Victoria University of Wellington, New Zealand.

McConchie, J.A., 1980. Implication of landslide activity for urban drainage. Journal of Hydrology. New Zealand $19,27-34$. 
McFadgen, B.G., 1985. Late Holocene stratigraphy of coastal deposits between Auckland and Dunedin, New Zealand. Journal of the Royal Society of New Zealand 15, 27-65.

McFadgen, B.G., 1989. Late Holocene depositional episodes in coastal New Zealand. New Zealand Journal of Ecology 12, 145-149.

McFadgen, B.G., 1994. Coastal stratigraphic evidence for human settlement. In: Sutton, D.G. (Ed.), The Origins of the First New Zealanders. Auckland Univ. Press, Auckland, pp. 195-207.

McGlone, M.S., 1981. Forest fire following Holocene tephra fall. Proceedings of Tephra Workshop. Victoria University, Wellington.

McGlone, M.S., 1983. Polynesian deforestation of New Zealand: a preliminary synthesis. Archaeology in Oceania $18,11-25$.

McGlone, M.S., 1989. The Polynesian settlement of New Zealand in relation to environment and biotic changes. New Zealand Journal of Ecology 12, 115-129.

McGlone, M.S., Basher, L.R., 1995. The deforestation of the upper Awatere Catchment, Inland Kaikoura Range, Marlborough, South-Island, New-Zealand. New Zealand Journal of Ecology 19, 53-66.

McGlone, M.S., Wilmshurst, J.M., 1999. Dating initial Maori environmental impact in New Zealand. Quaternary International 59, 5-16.

Montgomery, D.R., Schmidt, K.M., Greenberg, H.M., Dietrich, W.E., 2000. Forest clearing and regional landsliding. Geology 28, 311-314.

Newnham, R., 1999. Environmental change in Northland, New Zealand during the last glacial and Holocene. Quaternary International 57/58, 61-70.

Newnham, R.M., Lowe, D.J., McGlone, M.S., Wilmshurst, J.M., Higham, T.F.G., 1998a. The Kaharoa Tephra as a critical datum for earliest human impact in Northern New Zealand. Journal of Archaeological Science 25, $533-544$.

Newnham, R.M., Lowe, D.J., Matthews, B.W., 1998b. A late-Holocene and prehistoric environmental change from Lake Waikaremoana, New Zealand. Holocene 8, 443-454.

Newsome, P.F.J., 1987. Vegetative cover of New Zealand. Water and Soil Miscellaneous Publication, vol. 112. National of Water and Soil Organisation, Wellington.

Nichol, S.L., Augustinus, P.C., Gregory, M.R., Creese, R., Horrocks, M., 2000. Geomorphic and sedimentary evidence of human impact on the New Zealand coastal landscape. Physical Geography 21, 109-132.

O'Loughlin, C.J., 1974. The effect of timber removal on the stability of forest soils. Journal of Hydrology. New Zealand 13, 121-134.

O’Loughlin, C.L., 1984. Effectiveness of introduced forest vegetation for protection against landslides and erosion in New Zealand's steeplands. Symposium on Effects of Forest Land Use on Erosion and Slope Stability. New Zealand Forest Service, Honolulu, HI, pp. 275-280.

Page, M.J., Trustrum, N.A., 1997. A late Holocene lake sediment record of the erosion response to land use change in a steepland catchment, New Zealand. Zeitschrift für Geomorphologie 41, 369-392.

Page, M.J., Trustrum, N., 2000. High resolution lake sediments from New Zealand; a record of late Holocene storm history, vegetation change and landscape response. Pages Newsletter 3, 17-18.

Page, M.J., Trustrum, N.A., Dymond, J.R., 1994a. Sediment budget to assess the geomorphic effect of a cyclonic storm, New Zealand. Geomorphology 9, 169-188.

Page, M.J., Trustrum, N.A., DeRose, R.C., 1994b. A high resolution record of storm induced erosion from lake sediments, New Zealand. Journal of Paleolimnology 11, 333-348.

Page, M.J., Reid, L.M., Lynn, I.H., 1999. Sediment production from Cyclone Bola landslides, Waipaoa catchment. Journal of Hydrology. New Zealand 38, 289-308.

Phillips, C., Watson, A., 1994. Structural tree root research in New Zealand: a review. Landcare Research Science Series, vol. 71. Manaaki Whenua Landcare Research, Lincoln, 71 pp.

Phillips, C.J., Marden, M., Pearce, A.J., 1990. Effectiveness of reforestation in prevention and control of landsliding during large cyclonic storms. 19th World Congress, 5-11 August 1990. International Union of Forest Research Organizations, Montreal, pp. 340-350.

Pilotto, P.J., Goff, J.R., Weatherburn, D.C., 1998. A contemporary contamination record of stormdrain and harbour sediments, Wellington, New Zealand. Environmental Geology 36, 159-166.

Poole, A.L., Adams, N.M., 1994. Trees and shrubs of New Zealand. Field Guide Series. Manaaki Whenua Press, Lincoln, New Zealand. 
Preston, N.J., 1999. Event-induced changes in landsurface condition-implications for subsequent slope stability. Zeitschrift für Geomorphologie. Supplementband 115, 157-173.

Preston, N.J., Crozier, M.J., 1999. Resistance to shallow landslide failure through root-derived cohesion in East Coast hill country soils, North Island, New Zealand. Earth Surface Processes and Landforms 24, 665-675.

Reid, L.M., Page, M.J., 2003. Magnitude and frequency of landsliding in a large New Zealand catchment. Geomorphology 49, 71-88.

Rodolfi, G., 1997. Holocene mass movement activity in the Tosco-Romagnolo Apennines (Italy). In: Matthews, J.A., Brunsden, D., Frenzel, B., Gläser, B., Weiß, M.M. (Eds.), Rapid mass movement as a source of climatic evidence for the Holocene. Palaeoclimate Research. Gustav Fischer Verlag, Stuttgart, pp. 33-46.

Thomas, M.F., 2001. Landscape sensitivity in time and space - an introduction. Catena 42, 83-98.

Tomlinson, A.I., 1977. The Wellington and Hutt Valley flood of 20 December 1976. Technical Information Circular, vol. 154. New Zealand Meteorological Service, Wellington.

Trustrum, N.A., Page, M.J., 1992. The long-term erosion history of Lake Tutira watershed: implications for sustainable land use management. The Proceedings of the International Conference on Sustainable Land Use Management, 17-23 November 1991. Napier, Hawke Bay, New Zealand, pp. 212-215.

Trustrum, N.A., Blaschke, P.M., DeRose, R.C., West, A.W., 1990. Regolith changes and pastoral productivity declines following deforestation in steeplands of North Island, New Zealand. Transactions 14th International Soil Science Congress. Section I, Kyoto, Japan, pp. 125-130.

Trustrum, N.A., Gomez, B., Page, M.J., Reid, L.M., Hicks, M., 1999. Sediment production, storage and output: the relative role of large magnitude events in steepland catchments. Zeitschrift für Geomorphologie. Supplementband 115, 71-86.

Turner, G.M., 1997. Environmental magnetism and magnetic correlation of high resolution lake sediment records from Northern Hawke Bay, New Zealand. New Zealand Journal of Geology and Geophysics 40, 287-298.

Wilmshurst, J.M., 1997. The impact of human settlement on vegetation and soil stability in Hawke Bay, New Zealand. New Zealand Journal of Botany 35, 97-111.

Wilmshurst, J.M., McGlone, M.S., 1996. Forest disturbance in the central North Island, New Zealand, following the 1850 BP Taupo eruption. Holocene 6, 399-411.

Wilmshurst, J.M., McGlone, M.S., Partridge, T.R., 1997. A late Holocene history of natural disturbance in lowland podocarp/hardwood forest, Hawke Bay, New Zealand. New Zealand Journal of Botany 35, 79-96.

Wilmshurst, J.M., Eden, D.N., Froggatt, P.C., 1999. Late Holocene forest disturbance in Gisborne, New Zealand: a comparison of terrestrial and marine pollen records. New Zealand Journal of Botany 37, 523-540. 